DOI: 10.2478 /auseur-2021-0008

\title{
Central and Eastern Europe: An Invisible Sewing Shop
}

\section{Emese DOBOS}

$\mathrm{PhD}$ student, Corvinus University of Budapest,

Doctoral School of International Relations and Political Science, World Economy subprogramme, Central European Regional Research Group e-mail: emese-dobos-nagy@stud-uni-corvinus.hu; dobosemese1@gmail.com

\begin{abstract}
Developed countries started to outsource labour-intensive production processes to lower-cost countries decades ago such as the ones belonging to Central Eastern Europe, where subcontracting became significant from the 1950s. During the past few years, tendencies of relocation came to the fore and received a fresh boost because of the economic situation caused by the coronavirus pandemic. The growing need for shorter supply chains creates a noteworthy situation in the region's fashion industry. But we have to make a difference between the 'headquarter' country of the brand and the actual country of origin: even if luxury products are made here, the relations in production remain hidden.
\end{abstract}

Keywords: fashion industry, Central Eastern Europe, supply chain, relocation, outsourcing

\section{Introduction}

Central and Eastern European countries have been playing an important role in fashion production for decades: the factories are big employers, especially in rural areas, and the companies are partners of foreign, well-known 'household name' fashion brands. But why can we say that the region's fashion production is an invisible sewing shop? The answer is quite simple: the relations of production remain hidden. It is the purpose of the brands, and the regulations of the country of origin allow it. Even if there is no complete agreement on how to define Central and Eastern Europe, in the context of fashion production, Bulgaria, the Czech Republic, Latvia, Hungary, Poland, Romania, Slovakia, and Slovenia are among the most representative countries of this region (Faust 2005). In my paper, I focus on the Visegrád Four: Hungary, Poland, the Czech Republic, and Slovakia. 
The structure of my paper follows the concept of the international conference The Past, Present and the Future of Central Europe, organized by the Central Europe Research Group and Sapientia University's Department of International Relations and European Studies on 20 November 2020. It consists of three main parts: at first, I present the 'past' - the period from the intensified outsourcing activity till the regime change, the 'present' - from the regime change to the 2010s, a period characterized by the intense international competition and the global supply chain, and the 'future', i.e. the period from the 2010s, which is marked by relocation tendencies. My research method is qualitative: besides the literature review, I have also conducted deep interviews with representatives of the region's fashion industry with the aim of filling the gap caused by the lack of scientific and policy interest towards the fashion industry's production part.

The fashion industry covers several fields: from the production of raw materials, design, production to retail and even marketing (Steele-Major 2020). Under this term, I refer to the segment of fashion production - textile, garment, leather and shoes and fur industry -, where mainly garment production makes up the final pieces.

According to the latest figures of the World Trade Statistical Review 2020 (World Trade Organization 2019), the European Union (the 2019 trade data still includes Great Britain) is the second biggest garment exporter (after China), with 136 billion dollars of annual turnover, which means $27.6 \%$ of the world trade in clothing export. 2019 was the first year that brought a decline in the continuing growth of the garment trade. In Europe, the Romanian garment industry is the biggest employer (Spin360 2018). In the context of European garment production, in 2019, Italy exported clothes worth €12 billion to non-EU Member States (34\% of total extra-EU exports of clothes by value), followed by Germany (€6 billion, 16\%), Spain (€5 billion, 15\%), France (€4 billion, 13\%), and the Netherlands (€2 billion, $5 \%$ ) (Eurostat 2020). However, being the importer country and where production can actually take place is different, as the clothing production in Central Eastern Europe is significant, which I will specify later on.

The second part of the $20^{\text {th }}$ century and the globalization brought changes in the geography of production and economic structure as well. Developed countries with higher wages (with the purpose of the improvement of their competitiveness) outsourced high labour need, work-intense production processes to regions with lower wages - to Central and Eastern Europe as well. According to the 'experiences' of the world economy, this intensified outsourcing and the fragmentation of production are some of the main characteristics of fashion industry today besides electronics and mechanics. But while the latter mentioned industries were building strategic partnerships and operate their supply chains through subsidiaries, the fashion industry mainly works with independent companies and short-term contracts. The practice of subcontracting (contract work) means that the contractor (the fashion brand) owns the raw materials and other necessary equipment (such as zippers, 
buttons) and entrusts the subcontractor (the company who makes the production) to make the ordered garments after the specified documents and gaining a surcharge (Antalóczy-Sass 1998). Nevertheless, the pattern of outsourcing was not shaped only by lower wages, increasing productivity, scale of economics, and the growing costs in the home country, but transport, the development of (communication) technologies, (de)regulation of international trade and capital flow, trade conventions, the dismantling of the MFA quota system, ${ }^{1}$ and the European integration also affected (Molnár 2017) the tendencies besides the structure of the fashion industry, especially the growing mass-produced fast-fashion sector. Nowadays, the perception of fashion brands, consumer demands, and the need towards sustainability and transparency also affect the production decision of the fashion brands.

The fashion industry has a huge need for capital and labour as well (Mendes-de la Haye 2010). Globalization has radically redrawn the map of the fashion industry during the past decades. Previously, garments (and other fashion products) were made locally, but then production activities were outsourced: the lowest valueadded, mainly assembly and cut-make-trim processes took place in developing countries with lower wages (first in Asia, Central Eastern Europe and now to certain African countries as well) (Thomas 2007). As the fashion industry - and especially mass production - was looking for low wages, a tense price competition emerged (Robb 2016), and while developed countries (such as the ones in Western Europe) kept higher value-added processes (such as design, product development, and marketing), high labour-intense - i.e. less profitable - processes took place in Eastern Central Europe (Molnár 2017). While the fragmentation of production and outsourcing is a strategy for cost reduction, it also has a degrading effect on the traditional light industry's sectors, including fashion (Amighini-Rabellotti 2010).

Outsourcing can have different forms: companies can delocate their entire production, foreign direct investment (for example, buying of production capacities), strategic partnerships, and collaboration with different subcontractors - they can also outsource certain processes such as garment assembly (Amighini-Rabellotti 2010: 4).

\section{Why Is Central Eastern Europe an Invisible Sewing Shop?}

Meghan Markle Wears a Coat Made by Exploited Hungarian Workers; Revealed: The Romanian Site Where Louis Vuitton Makes Its Italian Shoes - I just mentioned a few from the headlines about issues when the hidden production relations within the fashion industry came to the surface and grabbed the attention of the

1 The MFA quota system (Multi Fibre Arrangement) regulated the trade of textile and garment products between 1974 and 1994 and incorporated the quote of quantity that was allowed to import from developing to developed countries. 
world press. But how is this possible in practice and legally? With the headway of globalization, we must make a difference between the 'home country', the headquarters of the fashion brands, and the country where production actually takes place. The higher market segments of the fashion industry, namely the luxury and the high-end, designer categories, are especially sensitive to their image because consumers connect the brands to a certain heritage, status, and high quality. And in the eye of the consumers, the lower market segments, such as fast-fashion and high-street brands, can more easily declare that their products are made in China, for example. Consumer perception is different with luxury brands, as Western Europe - especially France, Italy, and the United Kingdom - is considered to be home to 'luxury capitals'. So, production relations remain more hidden here as the country of origin, the 'Made in' label as a guarantee indicates craftsmanship, expertise and proper working conditions. However, as I have mentioned earlier, ethical, sustainable, and conscious consumption is growing among consumers (FutureBrand 2014). The regulation of the country of origin in the European Union allows that even luxury products be made in CEE countries under not quite decent working conditions and for low wages.

We must make a difference between the concept of invisibility and nontransparency. The first one refers rather to the non-existing relationship between customer and the production facility, that the exact place of origin is not indicated on the final product; invisibility also means the lack of appreciation of the manufacturers. On the other hand, non-transparency - as fashion brands do not represent their suppliers, and if they do, it is voluntary - can serve as a tool for hiding the not so decent working conditions and possible right violations, but it is also a tool of competition: fashion brands hide their suppliers because they do not want their rivals to know who they are working with.

There is currently no harmonized ruling and unified practice among the Member States of the European Union regarding the country of origin. The regulation in force allows but does not make it compulsory to use the 'Made in Europe' label if a product is made within the EU's borders nor does it inhibit the use of a single, concrete country. It is the interest of the fashion brands to indicate a high-prestige country (think about Italy and France, for example) as country of origin. This practice, however, is in contrast with the EU's interest, as consumers can differentiate products based on the $\mathrm{COO}$ (country of origin) sign, even if the products came from the internal single market. The 2004 amendment of the Act of 1997, Article CLV on consumer protection declares that the marking of the $\mathrm{COO}$ is not in compliance with the expectations, originated by the European community law, as consumer differentiation goes against the fundamental freedom of the free movement of goods. In 2014, a draft legislation was introduced to the European Parliament that would make it compulsory to mark the concrete country of origin, the country where the product underwent the last, substantial, economically justified processing or working. This draft was taken off the 
agenda of the Working Party on Consumer Protection and Information of the Council of the European Union. According to the existing case law of the EU, indication of the concrete country of origin is compulsory if a product is coming from outside the EU. But legal regulation and practice are different: Made in China can appear on products as removable stickers, or a product can be made there, apart from the last processing step, which is performed within the EU - and the latter will be indicated on the label as COO (Thomas 2007).

\section{Subcontracting: Garment Production in the V4 Countries}

The delocation of garment production started in the 1950s: first, Japanese, European, and American fashion brands outsourced their production to Asia and Western Germany (Federal Republic of Germany) to East European countries. After the Second World War, the formerly garment-maker craft industry / fashion salons / tailors and workshops were ceased, and the fashion salons were deprivatized, socialized, and confection production started. ${ }^{2}$ Quantity became important over quality, and factories exported the result of the 'overproduction' to the Comecon market (Csipes 2006). Subcontracting was significant in the centrally managed Hungarian textile and garment industry from the 1950s: first, for the Soviet socialist market and then for Western clients, as an additional activity in the first step. The capacity of the Hungarian confection industry started to grow in the 1970s (Valuch 2004). During the seventies and the eighties, collaboration with well-known global brands became more important: Hungarian trade and production companies were rushed to gain production rights: the products of Lee Cooper and Levi Strauss were made at the factory Május 1 and Pierre Cardin at Hungarotex (Valuch 2004).

The Hungarian Elegant Május 1 clothing factory was ranked among Central Europe's biggest and most advanced, developed garment factories (Csipes 2006). The factory's several thousand production series made from textile, leather, and fur products were exported - besides the Soviet market products' export to the United States of America, England, and Italy - before the regime change. After making uniforms, the big socialist factory started to produce female and male confection garments from 1955, and it took on the name Elegant, especially because of the Western markets. During its golden age, it employed 6,000 people in 7-8 facilities and also employed homeworkers (Vámos 2009). The Soviet export was politically compulsory and also offered advanced capacity planning for factories as quantity quotas were settled 1-1.5 years ahead. The remaining capacity of Elegant Május 1 was assigned to make sophisticated products 'finomkonfekció' (underwear and

2 Confection garment making is characterized by the mass production of ready-made garment after standardized size, that is, in contrast to made-to-order garment making. 
knitted products) that were imported by Denmark, England, Sweden, Germany, Italy, the USA, and Canada. Under state socialism, Hungarian factories received orders through the Light Industry Ministry's agreements, and thus the ministry decided on the contracts with foreign trade firms - Hungarotex and Tanimpex transmitted contract work and orders for Hungarian companies and dealt with the presence in foreign countries (Deés 2009). Within the framework of the 'bilateral socialist collaboration', post-socialist countries' fashion representatives agreed on different concepts and information packages, and also different models of clothes were exchanged between factories of the German Democratic Republic, Bulgaria, Poland, and Czechoslovakia. Even if there is an ongoing discussion between the Visegrád Countries about cooperation, collaboration, and economic convergence (Sáringer 2019), there is no example for any of these within the countries' fashion industry.

The so-called reform socialism had brought certain openness and relaxation to former economic principles in Czechoslovakia from 1967, in Hungary from 1968, and in the case of Poland from 1972, after Gorbachev had introduced his policy of glasnost (openness) and perestroika (restructuring) with the aim of reforming the Soviet Union. This policy also allowed making certain business connections with the West. Hungary and Poland had a relatively marketized economy thanks to certain reforms of the state socialist economy till the end of the 1980s (BohleGreskovits 2007). From the 1980s, six CEE countries became the European Union's main textile and garment export partners: Bulgaria, Hungary, Romania, the Czech Republic Slovakia, and Poland, where Western and contractor-subcontractor connections have been established - the basis of contract work was already given. With the end of the Comecon market and the Russian export, in parallel with the decreasing tendencies of the production background in Western Europe, wages were rising in the home countries, and they started to source products from Asia and CEE (Begg-Pickles-Smith 2003).

At the 1990s, when trade was liberalized, even if OPT agreements ${ }^{3}$ were left off, they remained in practice. Even if all six countries' garment and textile export had increased and almost every EU Member State's garment import has grown, there were relative winners and losers as well. Germany exported 60 percent of the garments from these six CEE countries in 1989, but then this rate fell back to 44 percent by 2000. Approximately the 7 percent of Italy's garment export came from the CEE countries, and this rate had increased to 17 percent by 2000. Poland and Hungary have lost some of their market share, but the Czech Republic's, Slovakia's, Bulgaria's, and Romania's share in supplier connections has increased. Trade

3 The OPT (outward processing trade) was a trade practice between the European Economic Community and Central Eastern European countries: raw materials, cut components, or even half-made products were sent to the latter countries' subcontractors and assembly activities took place in CEE, and then the final products were sent back to Western European countries tax free, where the products got the original country's 'Made in' label. 
between Romania and Italy has increased, while between Hungary and Germany has drastically decreased (Begg-Pickles-Smith 2003).

Contract work provides opportunity for an increased competitiveness for companies who are 'poor' in financial instruments and for the utilization of difference between labour costs, especially in so-called 'declining' industries, ${ }^{4}$ including the textile and garment industry as well (Antalóczy-Sass 1998). As I have written previously, contract work connections (between CEE countries and Western Europe) existed before the regime change or the transition to market economy, especially in the case of Yugoslavia's, Hungary's, Poland's, and Romania's fashion industry. From the 1990s, CEE countries have enjoyed a growing portion in contract work, and an increasingly important share of their export came from contract work.

Underwear, outer garments, and shoes made up steadily a significant percentage of the contract work export. That was preferred by the European Union - through its customs system -, while the EU tried to keep the raw material production within its borders. The contract work system of the EU has been geographically redrawn from the 1990s: the importance of Eastern European countries was realized because of the geographical proximity and the even lower labour costs compared to certain developing countries. From the second half of the 1980s, the underperformance of the Comecon market urged fashion companies to increase the portion of contract work in their activity as they were unable to increase their own products' (that were designed and made by them) export because of financial problems (lack of capital). The end of the Comecon market rapidly increased the rate of Western European contract work. From the beginning of the 1990s, $80-85 \%$ of the garment and shoe export of the Hungarian companies was done by contract work. The subservience to contract work was even increased during the second part of the $20^{\text {th }}$ century by another factor: the degradation of the textile factories. The lack of locally made and available textiles and other equipment limited the opportunities of the export of locally designed and developed products (Antalóczy-Sass 1998).

\section{Different Paths for the Visegrád Four Countries}

Nowadays, part of the former Május 1 clothing factory's activity is continued by Elegant Design Modelltervezố és Gyártás-elókészítố Zrt [Elegant Design Model Designer and Development of Production Private Limited Company]: 70\% of the outer garments manufactured at the factory are exported to France; the processes are performed through contract work. By this time, the company operates in an

4 There are two meanings of the declining industries: first, an industry can decline because its products have been replaced by new and better products, and, second, industries can decline because now it is cheaper to produce a certain product in another country and export it - the second definition refers to our case in terms of garment production. 
upgraded role as an intermediary: the facility based in Budapest is a site of the development of production and a logistic centre. Elegant Design is working together with some 20 Hungarian and 12 Romanian factories.

The transition to market economy and the increased need for competitiveness in the global market radically decimated the former industrial companies and segments. The transition also caused a geographical shift from the core countries to Eastern European and Far East countries, which were veritable repositories of low-cost labour force. But in parallel with this, fashion industry was taken to the back seat in terms of technological development and training. During the first two years after the regime change, the Hungarian fashion industry lost its market share faster than ever. In 1989, the Hungarian government cancelled the governmental guarantee of the Eastern export: that step meant making null and void almost half of the local factories' exports. The textile and garment factories were crippled and left without any help. The industry went through privatization, while its value was lost: numerous valuable machines were sold, and a significant number of the industry's professionals left the sector (TMTE 2009).

Contract work for mainly German, Italian, and French companies became significant in contrast with the former, steady Comecon-market (Hanzl-Pavlik 2003), so products made by Eastern European companies entered the market under foreign fashion brand names. Contract work in the fashion industry also means short-term contracts and insecurity, as a single garment is attached to a collection that is characterized by the actual season. That means about half a year's time. But we cannot exclude the opportunity of working together with fashion brands constantly, for longer time in practice.

The competitiveness of Eastern European fashion companies also has its drawbacks. Besides the mentioned geographical proximity, the closeness to Western culture, the formerly existed (and unexploited) working capacities, and the low respect and inadequate enforcement of national labour laws were also significant factors that shaped fashion brands' sourcing strategy (Clean Clothes Campaign 2016b). The report Labour on a Shoestring ${ }^{5}$ carried a warning that high-end, Italian and German shoe brand products are made with low-labour-cost Eastern European sweatshops ${ }^{6}$ through the OPT scheme, while the term 'Made in Europe' means a certain guarantee for the customers for proper working conditions and fair wages (Clean Clothes Campaign 2016a).

5 The Clean Clothes Campaign (established in 1998) is a global network dedicated to improving working conditions and empowering workers in the global garment and sportswear industries. Their experts have done research in Albanian, Bosnia-Herzegovinian, Macedonian, Polish, Romanian, and Slovakian shoe factories to examine the working conditions of the workers who are behind the well-known shoe brands.

6 A sweatshop (or sweat factory) is a factory or workshop, especially in the garment industry, where manual workers are employed at very low wages for long hours and under poor conditions. 
OPT was first used by German companies who started to rely on subsidiaries and subcontractors in foreign countries, and then the authorities of the European Union started to use the system as well. The system was explicitly supported by the German textile industry, which was expecting to stay in business more easily thanks to this measure. Increasing internationalization was accompanied by a steady decline in employment. Garment producers mostly transferred the remaining mass production parts and the less time critical items to foreign, low-cost facilities (Faust 2005: 16). The main destinations of the OPT activity were Romania, Bulgaria, Poland, Hungary, and the Czech Republic, as these countries are close to the Western European market. The mentioned countries became more and more significant subcontractors of the European market. Every country has been trying to specialize itself in a certain product category, and their export rate towards OECD countries significantly increased from the 1980s. From 1991, the former Yugoslavia's 'empty place' urged foreign investors and producers to look around and outsource their production into the direction of Hungary, Poland, Slovakia, the Czech Republic, Romania, Croatia, Russia, Slovenia, and Ukraine. There are examples for ultramodern facilities in garment production who were able to compete with Western European facilities and produce 'European quality level' (Cseh 1997).

While the textile and garment segments are not so significant economically, they are even more important from an employment point of view because of their great need of live labour. The charged sum of the contract work is based on the agreement of the contractor and the subcontractors' negotiation every time. It can be done directly between the two parties, but more often it was negotiated through intermediary agents. The newly developed situation has transformed the conditions under which employment contracts were concluded. On the one hand, the bargaining position of companies, who predominantly or exclusively earned their living from contract work, has deteriorated. On the other hand, the wages offered in the employment contract were also influenced by the growth of the 'contract work supply' with the entrance and emergence of other Eastern European countries in the contract work market. Anyway, thanks to the expertise and qualification of Hungarian labourers and their former experience in quality and work organization, management skills, Hungarian fashion companies could meet the highest requirements of the clients (Antalóczy-Sass 1998).

According to the country profile of the Clean Clothes Campaign (CCC), in the Czech Republic, 383 companies employ more than 10 thousand people in the garment sector, and its export rate is $73 \%^{7}$ (CCC 2016c). In contrast with the Hungarian situation, where companies were left alone without any governmental help, in the Czech Republic, a governmental agency, the CzechInvest ${ }^{8}$ connects production facilities

$7 \quad$ It is important to point out that the numbers were published before the COVID-19 pandemic that made a huge impact on employment.

8 CzechInvest is a governmental agency specialized in investment and business development, 
and companies to potential business partners and gives them help in applying for regional, municipal, and European Union funding, and this way they can invest into the development of their technology. The agency also supports foreign direct investment (FDI) and develops Czech small and medium enterprises (SMEs) besides acting as an intermediary stakeholder. We can also notice the specialization of Czech companies after the transition (to market economy). Veronika Ruppert, an independent Czech journalist, who made interviews with Czech fashion company owners and representatives for several years, points out the phenomenon that:

Most of the big colossuses that were put together without business sense broke apart. Lots of factories could not handle the transition, but there is actually a surprising number of factories that managed to go on or that started completely anew in the 1990s using the remaining human and technological capital. Czech factories produce high-end fine leather handbags (ELEGA) for local and foreign brands. The Tonak factory is one of the biggest producers of hats in the world (for example, even American Stetsons are made from their stock). Tilak successfully designs and produces high-quality urban outdoor garments in foreign markets, most of them in Japan. We have few stable shoe manufacturers focused on pracovní boty, ${ }^{9}$ mostly for the Czech and the German markets. We still have textile factories, there is the production of buttons, threads, and other necessary particles. We have several factories producing underwear; one of them, Triola, will celebrate its $100^{\text {th }}$ anniversary in 2 years. (Dobos 2019)

Poland's position is different, as there are companies that relied on traditional contract work and stayed, and there are several fashion companies that are significant in the global market. One example for producer facilities is Warmia SA, which was established in 1959, employs more than 1,000 people, and it works for Hugo Boss, Bugatti, and Burberry as well. Well-known Polish brands are Reserved, Mohito, and the CCC shoe brand.${ }^{10}$ By this time, there is no other Visegrád Country that would be home to such relevant fashion player in the global competition. According to CCC's latest (2015) data, 2,283 registered garment companies employ 97,200 people. The export rate is lower compared to other CEE countries, 'only' $50.7 \%$ - a significant production for the local market can be spotted here, which is in conformity with the big size of the Polish market.

There were 238 registered garment companies in Hungary according to CCC's 2017 data, and the sector employed more than 12 thousand people, with a $63 \%$ export rate. Comparing these data with the Czech Republic, Hungary's garment sector is definitely a bigger employer.

and it was established in 1992 by the Czech Republic's Industrial and Commercial Ministry.

10 In this paper, I do not examine the local production of the mentioned Polish fashion brands. 
Slovakia also had huge textile and garment factories during the $20^{\text {th }}$ century. The development of the Slovakian textile industry started after 1948: thanks to the forced industrialization, formerly existing factories were rebuilt and transformed, and new factories with modern technology were built (Slovakia was part of Czechoslovakia at that time). After the regime change, the Slovakian textile and garment industry decreased significantly in terms of rate of production and employment as well. Several companies were facing crisis after the changing business and economic conditions. According to the data from SARIO, ${ }^{11}$ textile and garment production fell by 30\% between 1990 and 1999. The main cause is the digressive path of the local industry, which was suffering because of the competitiveness of the developing countries' low labour costs. The beginning of the $21^{\text {st }}$ century brought renewal for the Slovakian segment that now employs 40 thousand people (that is a $30 \%$ decrease compared to the figures of 1990), and its export rate to Western European markets is over $75 \%$. The order of the Western fashion brands is stagnating because of cheaper Asian productions. Furthermore, moving towards upgrading and higher value-added activities was challenging for the Slovakian fashion industry. Low investment rate (and mood) and more expensive technology led to the depreciation of the companies' technological background. Likewise, according to SARIO's data, in 1990, 18 production companies were operating, whereas nowadays there are 218 of them (86 in textile and 132 in garment production, which usually employ more than 20 people, so we can talk about SMEs). But foreign capital is also in the sector: the Italian Mediconf and the Swiss Schiesser made smaller investments besides Danish and Belgian companies. Texicom operates in Ružomberok, and the BZVIL textile factory gave work for 5,000 people in the 1960s-70s: it was privatized in 1989.

CCC also examined the working conditions in the Polish and the Czech fashion industry and shed light on the fact that even if the two countries' production can be characterized by high quality, there are low wages, and salaries often do not reach the nationally guaranteed minimum wage levels. That was in 2015 (when the research was made): 312 dollars in Poland and 390 dollars in the Czech Republic. Their conclusion is that for a decent living workers should earn the triple amount of that wage.

\section{What Will the Future Bring?}

It is nearly impossible to see or predict what the future of the CEE and the Visegrád Four countries' fashion companies will be, as the COVID-19 pandemic has created unprecedented circumstances, and its long-term effect is unpredictable. Companies that rely on raw materials from Asia have suffered from the lack of supply and clients,

11 SARIO is a Slovakian investment and industrial development agency that was established in 2001 and operates under the supervision of the Ministry of Economy of the Slovak Republic. 
were ceased, or their orders were reduced. There is also a constant debate within the industry that there is need for a shorter supply chain and the reform of existing sourcing practices. But there is an ongoing phenomenon that can give hope to the fashion companies of the region: relocation tendencies (reshoring, nearshoring, and onshoring) have been examined and spotted for the 2010s. Relocation as the action of moving to a new place primary focuses on fashion on moving away from Asian production, and it takes place in nearshoring as the practice of transferring a business operation to a nearby country, especially as a preference over a more distant one, and backshoring, or onshoring as the repatriation of production to the home country (Fratocchi et al. 2014).

While the mass production is taking place in Asia, smaller production series in the higher market segment are performed within the region. Two decades ago, European and American fashion brands were in a hurry to outsource their production to Asia as they wanted to reduce their costs. The traditional supply chain of fashion is facing challenges due to the convergence of labour cost. While in 2005, Chinese wages were one tenth of the American salaries, that rate is now 'only' a one third. Time is also money: with geographically closer production, significant costs can be saved. For American fashion brands, Mexico now offers lower labour, and it is closer to the American market (Amed 2019). Even if labour costs are higher in Eastern Europe than in China, that rate changes. While wages in Turkey were five time more than in China, now they are less than the double. And we have to add the saving of cost in transport and time. 'Now deadline has become more important than price. Why are fashion brands produced here? It is simple. It is cheaper than in the Western European countries, while we offer the same quality. Formerly, the rate was 2.5 between production price and final price. Now it is bigger and bigger' - says Anna Szabó Hannauerné, Head of the Textile and Garments Section of the National Association of Entrepreneurs and Employers (VOSZ) (Dobos 2019).

The fashion industry has arrived at a crossroads where speed beats costs regarding marginal advantages, and concerns of sustainability are getting stronger. Transportation is also significant: sea transport is the most common one, but it takes time: it takes around 30 days for a parcel to reach Western European markets from Asia, while air transport is considered to be too expensive (Andersson et al. 2018), and the 'slowness' of transport is likely unable to serve the current speed of the fashion industry. Former advantages of delocation are also derogated by geopolitical tension, trade agreements, and the insecurity caused by fluctuation in exchange rates as well.

Conventional organizational structures and forecast-driven supply chains have been formerly declared not to be adequate to meet the challenges of volatile and turbulent demand which typify fashion markets today, and there is a constant call for agile supply chain (Christopher-Lowson-Peck 2004). Even if there is a tendency for the rationalization of the supply chain (that means lesser suppliers for fashion 
brands), relying on a smaller number of suppliers can increase the risk of supply chain disruption (McMaster et al. 2020). Even if we can declare delocation as a tendency, increasing costs and management challenges have urged several fashion brands to reconsider the direction and the expansion of their production, namely relocation, and switch to local suppliers (Robinson-Hsieh 2016).

\section{Conclusions}

Several industry reports predict relocation tendencies and the growing importance of the Central European region, including the Visegrád Four countries, as the fashion industry's supply chains are not serving the interest of the brands - referring to long lead times and growing costs. The tradition, the heritage, the expertise, and the existing connections are all respected and noticed by the clients. The years 2020 and 2021 with the COVID-19 have brought unprecedented times, and as the regions' fashion companies rely on foreign fashion brand orders, their future is mainly in their hands as well. The pandemic also had a devastating effect on the global and the local economies. Even if we consider relocation an ongoing and continuous, intensifying tendency, local fashion industries are facing several challenges, and numerous factors will actually shape the associated phenomena in the long run. In the short term, the survival of the companies is the top priority, while several other challenges are hanging over their head and will be subjects of my further research. One of the biggest challenges are the urgent lack of workforce and its aging tendencies. The lack of industrial policy and the cessation of trainings means an aging workforce, and there is barely any second generation on the horizon. Even if high-end, luxury, household name fashion products are made in the region, who will get the 'credit'? Since working in fashion production is underpaid compared to the complexity and the exactitude of the job, it is understandable that the young generation is looking for other occupations. But if we look at the undeservedly neglected social sustainability: fashion companies could be big and inclusive employers, as the segment gives job to thousands of people in rural areas and to people with disabilities. With contract work and in the trap of subcontracting, dependency means a lifebuoy but not a possible path for the companies who are suffering from lack of capital, which makes challenging for them to move forward. 


\section{References}

ABNETT, Kate. 2016. Does Reshoring Fashion Manufacturing Make Sense? Available at: https://www.businessoffashion.com/articles/intelligence/canfashion-manufacturing-come-home. Last accessed on: 17.01.2020.

AMED, Imran. 2019. The State of Fashion 2019. Available at: https://www. mckinsey.com/industries/retail/our-insights/the-state-of-fashion-2019-a-year-ofawakening. Last accessed on: 19.01.2020.

AMIGHINI, Alessia-RABELLOTTI, Roberta. 2010. How Do Italian Footwear Industrial Districts Face Globalization. European \& Planning Studies 14(4): 485502.

ANDERSSON, Johanna et al. 2018. Is Apparel Manufacturing Coming Home? Nearshoring, Automation, and Sustainability - Establishing a DemandFocused Apparel Value Chain. Available at: https://www.mckinsey.com/ / media/mckinsey/industries/retail/our \% 20 insights/is $\% 20$ apparel $\% 20$ manufacturing\%20coming\% 20home/is-apparel-manufacturing-coming-home_ vf.pdf. Last accessed on: 28.05.2021.

ANTALÓCZY, Katalin-SASS, Magdolna. 1998. A bérmunka szerepe a világgazdaságban és Magyarországon. Közgazdasági Szemle 45(7-8): 747-770.

BAIR, Jennifer. 2005. Global Capitalism and Commodity Chains: Looking Back, Going Forward. Competition \& Change 9(2): 153-180.

BEGG, Bob-PICKLES, John-SMITH, Adrian. 2003. Cutting It: European Integration, Trade Regimes, and the Reconfiguration of East-Central European Apparel Production. Environment and Planning A 35(12): 2191-2207.

BOHLE, Dorothee-GRESKOVITS, Béla. 2007. Neoliberalism, Embedded Neoliberalism and Neocorporatism: Towards Transnational Capitalism in Central-Eastern Europe. West European Politics 30(3): 443-466.

CHRISTOPHER, Martin-LOWSON, Robert-PECK, Helen. 2004. Creating Agile Supply Chains in the Fashion Industry. International Journal of Retail \& Distribution Management 32(8): 367-376.

CLEAN CLOTHES CAMPAIGN. 2016a. Labour on a Shoestring. Available at: https:// cleanclothes.org/resources/recommended-reading/labour-on-a-shoestringfactsheet. Last accessed on: 18.01.2020.

2016b. European Garment Workers Face Forced Overtime and Poverty Wages. Available at: https://www.business-humanrights.org/en/clean-clothes-campaigngarment-workers-face-forced-overtime-and-poverty-wages-in-poland-czechrepublic. Last accessed on: 14.03.2020.

2016c. Country Profile: Czech Republic. Available at: https://cleanclothes.org/ file-repository/livingwage-europe-country-profiles-czech-republic/view. Last accessed on: 01.07.2021. 
CSEH, József. 1997. A textil- és textilruházati ipar helyzete, a versenyképességét meghatározó tényezók. Available at: http://edok.lib.uni-corvinus.hu/233/1/ MT13_Cseh.pdf. Last accessed on: 19.01.2020.

CSIPES, Antal. 2006. Divattükör. Budapest: Osiris.

DEÉS, Enikő. 2009. A nagyüzem és a kreativitás. In: Simonovics, Ildikó-Valuch, Tibor (eds), Öltöztessük fel az országot! Divat és öltözködés a szocializmusban. Budapest: Argumentum Kiadó. 280-288.

DOBOS, Emese. 2019. A félmilliós luxusruhákat készítő magyarok sokszor a minimálbért sem kapják meg. Available at: https://hvg.hu/kkv/20191202_stella_ meccartney_varroda_ruhaipar. Last accessed on: 19.01.2020.

FAUST, Michael. 2005. Reorganization and Relocation in the German Fashion Industry. Paper prepared for the conference Organisational Configurations and Locational Choices of Firms: Responses to Globalisation in Different Industry and Institutional Environments, May 2005, Göttingen.

FRATOCCHI et al. 2014. Manufacturing Reshoring: Threat and Opportunity for East Central Europe and Baltic Countries. In: Zhuplev, A.-Liuhto, K. (eds), GeoRegional Competitiveness in Central and Eastern Europe, the Baltic Countries, and Russia. IGI Global. 83-118. http://doi:10.4018/978-1-4666-6054-0.ch004.

FUTUREBRAND. 2014. Made in: The value of Country of Origin for Future Brands. Available at: https://carlobattisti.files.wordpress.com/2015/06/made_in_final_ hr.pdf. Last accessed on: 12.01.2020.

HANZL, Doris-HAVLIK, Peter. 2003. Textiles in Central Eastern Europe and Russia: A Comparative Analysis in the European Context. Journal of Economics and Business 6(2): 63-88.

MCMASTER, May et al. 2020. Risk Management: Rethinking Fashion Supply Chain Management for Multinational Corporations in Light of the COVID-19 Outbreak. Journal of Risk and Financial Management 13(8): 1-16.

MENDES, Valerie-DE LA HAYE, Amy. 2010. Fashion since 1900. London: Thames \& Hudson.

MOLNÁR, Ernő. 2017. Globális értékláncok és térbeli gazdasági egyenlőtlenségek: miről mesél a textil- és ruházati ipar változó földrajza? Földrajzi Közlemények 141(3): 216-225.

ROBINSON, Pamela K.-HSIEH, Linda. 2016. Reshoring: A Strategic Renewal of Luxury Clothing Supply Chains. Operations Management Research 9: 89-101.

SÁRINGER, János. 2019. The Visegrád Four in the World. In: Conference handbook. International Conference on BRI and Indo-Pacific Strategy: Transformation of Geopolitics and Regional Responses, 5-6 December 2019, National Chengchi University. Co-organizers: International College of Innovation, National Chengchi University (ICI-NCCU) and Oriental Business and Innovation Center, Budapest Business School (OBIC-BBS), University of Applied Sciences and the Hungarian Central Bank. National Chengchi University, Taiwan. 162-171. 
SPIN360. 2018. European Social Dialogue in the Textile and Clothing Industry: Results, Strategic Analysis, Future Perspectives. Available at: http://spin360.biz/ report_capacitybuilding/wp-content/uploads/2018/01/CapacityBuilding-HU. pdf. Last accessed on: 19.01.2020.

STEELE, Valerie-MAJOR, John S. 2020. Fashion Industry. Encyclopedia Britannica. Available at: https://www.britannica.com/art/fashion-industry. Last accessed on: 1.07.2021.

THOMAS, Dana. 2007. Deluxe. How Luxury Lost Its Luster. New York: Penguin Books.

TMTE - Textilipari- és Múszaki Tudományos Egyesület. 2009. A magyar textilés ruhaipar kutatás-fejlesztési és innovációs stratégiája. Available at: http:// tmte.hu/_userfiles_/tmte/071_texplat_jovokep_091210.pdf. Last accessed on: 19.01.2020.

VALUCH, Tibor. 2004. A lódentól a miniszoknyáig. A XX. század második felének magyarországi öltözködéstörténete. Budapest: Corvina.

VÁMOS, Magda. 2009. Divat a szocializmusban. In: Simonovics, Ildikó-Valuch, Tibor (eds), Öltöztessük fel az országot! Divat és öltözködés a szocializmusban. Budapest: Argumentum Kiadó. 288-293.

YOUNG, Robb. 2016. New Era for Chinese Fashion Manufacturers. Available at: http://www.businessoffashion.com/community/voices/discussions/canchina-still-compete-as-the-worlds-fashion-factory/new-era-for-chinese-fashionproduction-manufacturers. Last accessed on: 12.01.2020. 